\title{
Research on Construction Risk Management of Underground Engineering Based on AHP-Fuzzy Comprehensive Evaluation Method
}

\author{
Zhichao Han*1, Jun Zhu², Jianduo Wang ${ }^{3}$ \\ ${ }^{1}$ Space Support Department, Space Engineering University, Beijing China \\ ${ }^{2}$ Space Support Department, Space Engineering University, Beijing China \\ ${ }^{3}$ Space Support Department, Space Engineering University, Beijing China
}

\begin{abstract}
In order to strengthen the construction risk management of underground engineering projects, reduce the probability of accidents, and ensure that the underground engineering completes the construction tasks on schedule, the article relies on a certain subway engineering project to carry out research from the aspects of risk identification, risk factor analysis, and risk factor evaluation. The article adopts analytic hierarchy process and fuzzy comprehensive evaluation method to carry out risk factor evaluation weight analysis and risk system evaluation in the construction process, and then realize reasonable prediction and evaluation of construction risk factors. Finally, this essay sorts out the prevention and control measures of underground engineering construction risk management from five aspects of personnel, machinery, management, environment and technology, and then provides auxiliary decision-making for underground engineering construction risk management.
\end{abstract}

\section{INTRODUCTION}

The development and utilization of underground space are an important way to solve urban problems and improve people's living environment[1]. Underground engineering can well solve a series of problems brought about by rapid economic development and insufficient urban available space[2]. Underground building development need the qualities of long duration, the huge scale for construction, in addition, totally provision engineering. Development geology for underground building will be complex, prompting the incessant event from claiming different building accidents, which can easily lead to casualties, equipment damage, and construction delays[3]. The requisition of Hazard administration in the development procedure of underground building is fundamental.

Most underground engineering accidents occur in the construction phase, and risk management during the construction phase has always been the focus of research in the field of underground engineering. Tang Yuchun[4] believes that there are mainly construction personnel risks, shield construction safety risks, construction environment safety risks, and organization management safety risks during the construction phase; Qian Qihu[3] believes that the underground engineering construction process mainly faces safety management hazards, water, and mud inrush geological disasters, and rock burst geological disasters. It can be seen from the above research states that there are many risk factors in the process of underground engineering construction, involving multiple dimensions

*E-mail: 2925941493@qq.com such as personnel, management, and machinery. In the methodology from claiming danger management, deciding those weight of danger figures may be those establishment to hazard administration and aversion. Pan Xiuming proposed to carry out hierarchical management of risks in the construction process[5]; Shen Xueping used rough set theory and principal component analysis, combined with accident data to calculate the comprehensive weight of risk factors[6]; Wang Yaliang[7] proposed risk management and control measures by calculating the subjective weight, objective weight, main factors and secondary factors of risk factors.

The above research results show that in the methodology for underground building development hazard management, the utilization for danger element investigation and weight determination strategies could deal with and then control dangers great. The research process uses the analytic hierarchy process and fuzzy evaluation method to increase the objectivity of calculation. Rank the importance of risk factors, and establish a safe production index system, hoping to provide help for the risk management of underground engineering construction.

\section{PROJECT OVERVIEW}

The research object of this article is a subway project. In figure out those danger figures that might influence the development process, then establish the risk factor evaluation index system during the construction stage, and 
finally put forward feasible risk management control measures through risk assessment.

The construction environment of the subway project is a long-distance crossing cobblestone stratum. Shield construction method is affected by geological conditions and water ripple conditions. The landform of the project construction section before YDK18+840 belongs to the floodplain. Before YDK17+360, it is located on T156 Road, and after YDK17+360 it passes through residential and commercial areas. The territory will be low in the middle, secondary looking into both sides, and the ground rise is the middle of $1518.21-1527.56 \mathrm{~m}$. After YDK18+840, this section is mainly located on the main road in the urban area, with residential areas on both sides. The terrain of this section is low in the east and high in the west, and the ground elevation is between 1519.23$1528.76 \mathrm{~m}$.

\section{RISK ASSESSMENT}

\subsection{Risk factor identification}

The underground construction risk factors were collected from 7 experts and 3 construction leaders through a questionnaire survey. After 3 rounds of feedback, 1 concentrated discussion and reading subway constructionrelated journals, papers, and specifications, combining with the geological watermark exploration analysis report and the building exploration results, it is finally determined that the risk factors in the construction process of the underground engineering include 5 first-level risk indicators and 23 second-level risk indicators. The rundown for danger figures is demonstrated in "Table 1".

Table1. LIST OF RISK FACTORS

\begin{tabular}{|c|c|c|}
\hline $\begin{array}{c}\text { Serial } \\
\text { Number }\end{array}$ & $\begin{array}{c}\text { Risk } \\
\text { Category }\end{array}$ & Risk Factor Description \\
\hline \multirow{4}{*}{1} & \multirow{4}{*}{$\begin{array}{l}\text { Personnel } \\
\text { risk }\end{array}$} & Organizational structure risk \\
\hline & & Risk awareness \\
\hline & & Security training risks \\
\hline & & Emergency response risk \\
\hline \multirow{4}{*}{2} & \multirow{4}{*}{$\begin{array}{l}\text { Construction } \\
\text { machinery }\end{array}$} & Operational use risk \\
\hline & & Maintenance risk \\
\hline & & Special equipment management risk \\
\hline & & Equipment deployment risk \\
\hline \multirow{6}{*}{3} & \multirow{6}{*}{$\begin{array}{l}\text { Construction } \\
\text { environment }\end{array}$} & Geological watermark risk \\
\hline & & Underground pipeline risk \\
\hline & & Personnel construction environment risk \\
\hline & & Ground building risk \\
\hline & & Natural climate risk \\
\hline & & $\begin{array}{c}\text { National political policy, economic policy } \\
\text { risk }\end{array}$ \\
\hline \multirow{6}{*}{4} & \multirow{6}{*}{$\begin{array}{l}\text { Construction } \\
\text { management }\end{array}$} & Risk management during project operation \\
\hline & & $\begin{array}{c}\text { Fire risk } \\
\end{array}$ \\
\hline & & Electrical management risks \\
\hline & & On-site safety management risk \\
\hline & & Regulatory risk \\
\hline & & Risk Management System Risk \\
\hline \multirow{3}{*}{5} & \multirow{3}{*}{$\begin{array}{l}\text { Construction } \\
\text { Technology }\end{array}$} & Geological watermark survey risk \\
\hline & & Construction plan risk \\
\hline & & Construction personnel technical level risk \\
\hline
\end{tabular}

\subsection{Risk factor analysis}

Based on the above list of risk factors, we further analyze personnel risks, construction engineering machinery risks, construction environmental risks, construction management risks, and construction technology risks.

\subsubsection{Personnel risk.}

Common personnel risks are manifested by the lack of knowledge of the risk management system and insufficient management experience of risk managers. Throughout the management process, there will be not kidding mischance taking care of, neglect of anticipation and prevention, specific measures, and neglect of safety thinking training; the risk management organization structure is unreasonable, and type-of-work level fail to achieve step-by-step risk management; insufficient understanding of "Hain's Law".

\subsubsection{Construction machinery risk}

Equipment cannot be effectively integrated, lack of intelligence, and high professional requirements; wrong equipment status and performance can easily lead to misoperation, wrong command, and equipment accidents; equipment involves many types of work, and equipment management is prone to loopholes; the daily working hours of equipment are long, and equipment maintenance, inspection and repair are not timely or in place.

\subsubsection{Construction environment risk}

Compared with the above ground, the construction environment is more complicated and unknown, and the risk of occurrence is higher; according to the existing data, the underground rock formation and water ripple situation are investigated, and the basic situation is not timely ; the gas composition in the underground environment is more complex, most of the gas's impact on the human body is a long-term process, and there is no effective means to improve, the construction workers are prone to fear and panic.

\subsubsection{Construction management risk}

Regulations and systems related to construction management are not perfect and specific enough, and there are no specific measures; there are many elements of construction management, mainly including people, machinery, fire protection, ventilation, water supply, and drainage, power supply and distribution, often appearing management confusion, disconnection, out of control, which may lead to potential accidents; development oversaw economy is the administration of the entire methodology, and most managers can't manage before, during and after the event.

\subsubsection{Construction technology risk}

Underground engineering construction is a highly 
integrated professional operation. There are many applications in the construction process and various types of work are involved, resulting in high technical risks in the construction itself. Before the construction, the survey of the geological water pattern in the relevant area was incomplete, and the constructors did not know the specific conditions of the geological rock formations and groundwater flow, which led to the subway construction accident; construction personnel can not use construction technology proficiently.

\section{RISK ASSESSMENT}

\subsection{Risk evaluation index system construction}

\subsubsection{Risk evaluation index selection}

Based on the list of risk factors in "Table 1" above, the analytic hierarchy process indicators are selected as showed in "Table 2".

Table2. RISK EVALUATION INDEX

\begin{tabular}{|l|c|c|}
\hline Target Layer A & $\begin{array}{c}\text { Criterion } \\
\text { Layer B }\end{array}$ & Index Layer C \\
\hline Safety risks in & Personnel & Organizational structure C1 \\
\hline
\end{tabular}

\begin{tabular}{|c|c|c|}
\hline \multirow{22}{*}{$\begin{array}{c}\text { subway } \\
\text { construction }\end{array}$} & \multirow[t]{3}{*}{ risk B1 } & Risk awareness $\mathrm{C} 2$ \\
\hline & & Safety training C3 \\
\hline & & Emergency response $\mathrm{C} 4$ \\
\hline & \multirow{4}{*}{$\begin{array}{c}\text { Construction } \\
\text { machinery } \\
\text { risk B2 }\end{array}$} & Operation use C5 \\
\hline & & Maintenance C6 \\
\hline & & Special equipment management $\mathrm{C} 7$ \\
\hline & & Equipment deployment C8 \\
\hline & \multirow{6}{*}{$\begin{array}{c}\text { Construction } \\
\text { environment } \\
\text { risk B3 }\end{array}$} & Geological watermark C9 \\
\hline & & Underground pipeline $\mathrm{C} 10$ \\
\hline & & Personnel construction environment $\mathrm{C} 11$ \\
\hline & & Ground building C12 \\
\hline & & \begin{tabular}{|c|} 
Natural climate $\mathrm{C} 13$ \\
\end{tabular} \\
\hline & & $\begin{array}{l}\text { National political policy, economic policy } \\
\text { C14 }\end{array}$ \\
\hline & \multirow{6}{*}{$\begin{array}{l}\text { Construction } \\
\text { management } \\
\text { risk B4 }\end{array}$} & Project operation period management $\mathrm{C} 15$ \\
\hline & & Fire prevention C16 \\
\hline & & Electrical Management C17 \\
\hline & & Site safety management $\mathrm{C} 18$ \\
\hline & & Rules and regulations $\mathrm{C} 19$ \\
\hline & & Risk management system C20 \\
\hline & \multirow{3}{*}{$\begin{array}{c}\text { Construction } \\
\text { technology } \\
\text { risk B5 }\end{array}$} & Geological watermark risk $\mathrm{C} 21$ \\
\hline & & Construction plan C22 \\
\hline & & $\begin{array}{l}\text { Technical level of construction personnel } \\
\text { C23 }\end{array}$ \\
\hline
\end{tabular}

\subsubsection{Risk evaluation index system construction}

According to "Table 2", the analytic hierarchy process evaluation index system is shown in "Figure 1".

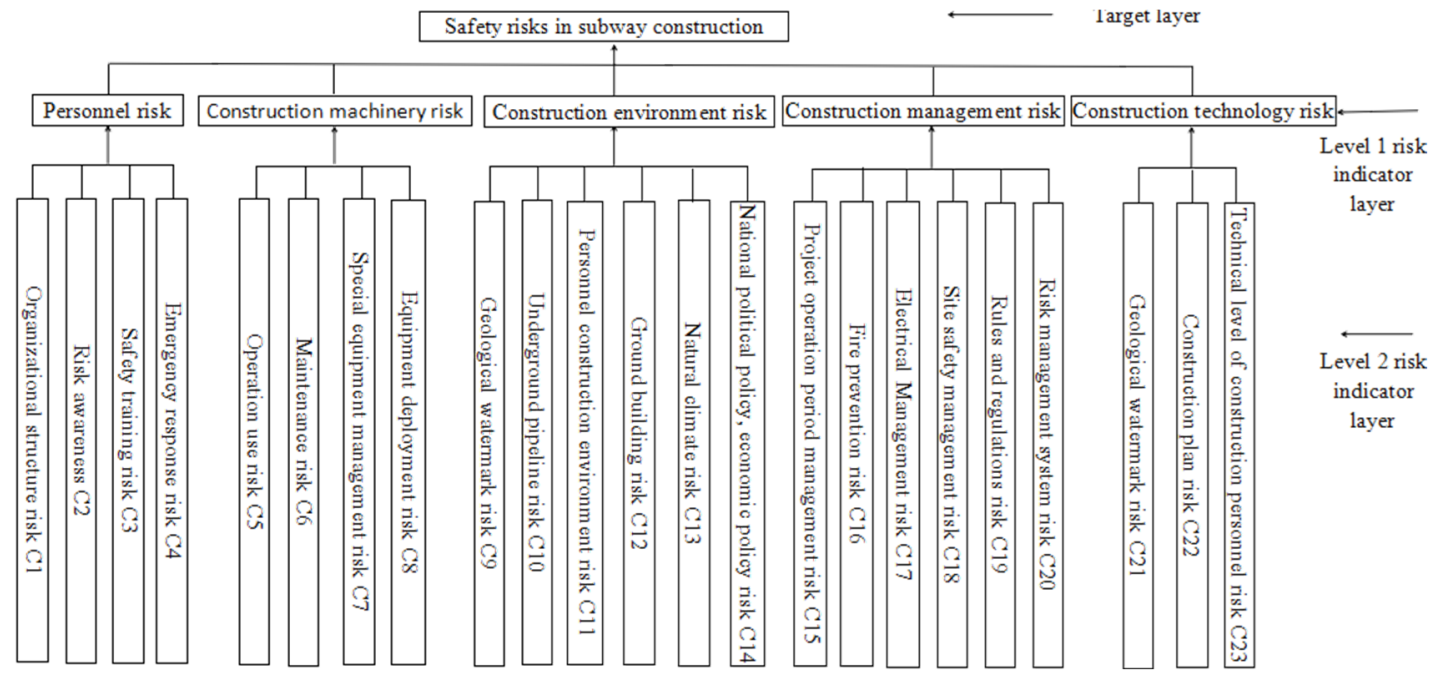

Fig 1. Risk Evaluation Index System

\subsection{Risk assessment analysis}

\subsubsection{Use AHP to determine the weight of risk factors}

According to "Figure 1", through consultation with project managers and risk management experts, and organize questionnaire surveys to measure the relative importance of risk factors, and calculate the weights of each factor.

The first step is to use "YAAHP" software to draw the construction safety risk hierarchy analysis structure diagram of the subway project, as showed in "Figure 2". 


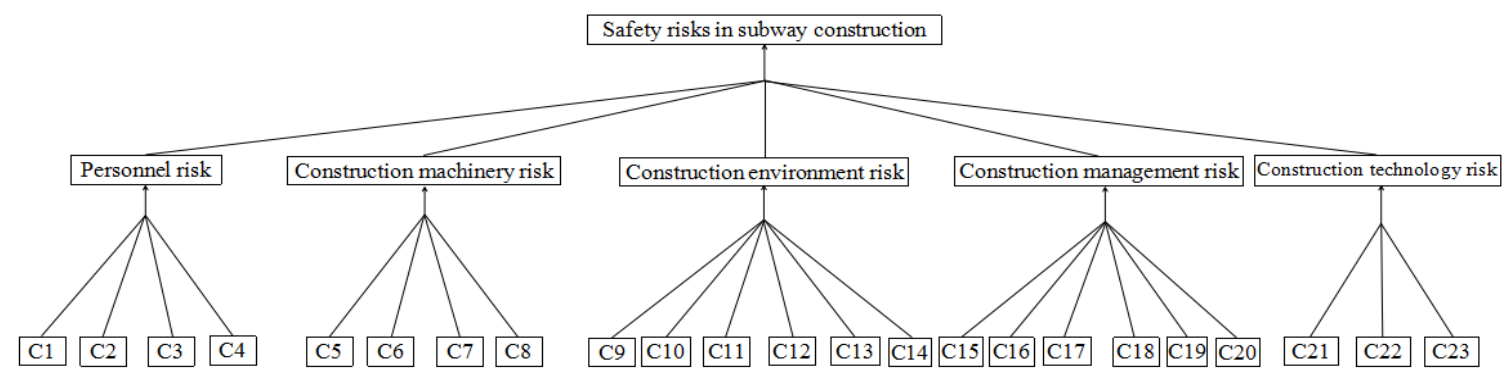

Fig 2. Risk Hierarchy Analysis Structure

The second step consists of qualitatively and quantitatively analyze and evaluate each risk factor and project risk degree through the fuzzy-level method. Building the judgment matrix of each level in turning.
Compare the importance of each element of the first-level risk index level $\mathrm{B}$ to the target level $\mathrm{A}$ and establish a judgment matrix. Perceive "Table 3" and "Table 4" to points.

Table3. First-level risk index B-level judgment matrix

\begin{tabular}{|c|c|c|c|c|c|}
\hline First-level risk & Personnel risk B1 & $\begin{array}{c}\text { Construction machinery } \\
\text { risk B2 }\end{array}$ & $\begin{array}{c}\text { Construction } \\
\text { environment risk B3 }\end{array}$ & $\begin{array}{c}\text { Construction } \\
\text { management risk B4 }\end{array}$ & $\begin{array}{c}\text { Construction } \\
\text { technology risk B5 }\end{array}$ \\
\hline Personnel risk B1 & 1 & 7 & 3 & 2 & 4 \\
\hline $\begin{array}{c}\text { Construction machinery } \\
\text { risk B2 }\end{array}$ & $1 / 7$ & 1 & $1 / 3$ & $1 / 4$ & $1 / 2$ \\
\hline $\begin{array}{c}\text { Construction } \\
\text { environment risk B3 }\end{array}$ & $1 / 3$ & 3 & 4 & 1 & 3 \\
\hline $\begin{array}{c}\text { Construction } \\
\text { management risk B4 }\end{array}$ & $1 / 2$ & 5 & 2 & $1 / 3$ & 1 \\
\hline $\begin{array}{c}\text { Construction } \\
\text { technology risk B5 }\end{array}$ & $1 / 4$ & 2 & $1 / 2$ & \\
\hline
\end{tabular}

Table4. First-level risk index B-level judgment weight

\begin{tabular}{|c|c|c|c|c|}
\hline $\mathrm{W}_{\mathrm{B} 1}$ & $\mathrm{~W}_{\mathrm{B} 2}$ & $\mathrm{~W}_{\mathrm{B} 3}$ & $\mathrm{~W}_{\mathrm{B} 4}$ & $\mathrm{~W}_{\mathrm{B} 5}$ \\
\hline 0.425 & 0.053 & 0.108 & 0.301 & 0.113 \\
\hline
\end{tabular}

The characteristic maximum value of the first level risk indicator level $\mathrm{B}$ to the target level $\mathrm{A} \lambda=5.067$. The weight calculation results are shown in "Table 4".

Consistency index:

$$
C I=\frac{(\lambda-n)}{(n-1)}
$$

$\lambda$ is the largest eigenvector of the judgment matrix, $n$ is the order of the judgment matrix.

$\mathrm{CI}=0$, have complete consistency;

CI close to 0 , have satisfactory consistency;

CI bigger, the more serious the inconsistency.

$$
C R=\frac{C I}{R I}
$$

Calculate the relative weight of each indicator to the indicator of the previous level according to the judgment matrix, by formula (1) and formula (2) combined with "Tables 5 and 6", calculate the consistency ratio CR to see if the matrix meets the consistency requirements. If $\mathrm{CR}<$ 0.1 , the consistency requirement is met.

$\mathrm{CI}=0.0167$ calculated from formula (1) and formula (2).

By looking up "Table 5": When $\mathrm{n}$ is equal to 5, $\mathrm{RI}=1.12$.
The consistency test result is $\mathrm{CR}=\mathrm{CI} / \mathrm{RI}=0.0149<0.1$, which satisfies the consistency condition.

Table5. Average random consistency index value of judgment matrix RI

\begin{tabular}{|c|c|c|c|c|c|c|c|c|c|}
\hline $\mathbf{n}$ & 1 & 2 & 3 & 4 & 5 & 6 & 7 & 8 & 9 \\
\hline $\mathbf{R I}$ & 0 & 0 & 0.52 & 0.89 & 1.12 & 1.26 & 1.36 & 1.41 & 1.46 \\
\hline
\end{tabular}

Compare the secondary risk indicators of each primary risk indicator, calculate the judgment matrix of construction personnel risk group, construction machinery risk group judgment matrix, construction environment risk group judgment matrix, construction operation risk group judgment matrix, and construction technology group judgment matrix. Do the hazard assessment list grid calculation, complete the consistency test of each risk factor, and obtain the weight index of the risk evaluation index of each index layer. After calculation, each judgment matrix can make way for the consistency test. See "Table 6-10" for details.

Table6. Personnel Risk (B1) Group Judgment Matrix

\begin{tabular}{|c|c|c|c|c|}
\hline Personnel risk & $\mathrm{C} 1$ & $\mathrm{C} 2$ & $\mathrm{C} 3$ & $\mathrm{C} 4$ \\
\hline $\mathrm{C} 1$ & 1 & 2 & 6 & 3 \\
\hline $\mathrm{C} 2$ & $1 / 2$ & 1 & 3 & 2 \\
\hline $\mathrm{C} 3$ & $1 / 6$ & $1 / 3$ & 1 & $1 / 2$ \\
\hline $\mathrm{C} 4$ & $1 / 3$ & $1 / 2$ & 2 & 1 \\
\hline
\end{tabular}

From "Table 6" we know the weight between criterion layers W1 $=(0.2727,0.5445,0.0909,0.0909)$. Computed by $\lambda=4.0011$. The consistency check result is $\mathrm{CR}=\mathrm{CI} / \mathrm{RI}=0.0012<0.1$, satisfy the consistency conditions. 
Table7. Construction machinery risk (B2) group judgment matrix

\begin{tabular}{|c|c|c|c|c|}
\hline Construction machinery risk & C5 & C6 & C7 & C8 \\
\hline C5 & 1 & 5 & 7 & 9 \\
\hline C6 & $1 / 5$ & 1 & 3 & 5 \\
\hline C7 & $1 / 7$ & $1 / 3$ & 1 & 3 \\
\hline C8 & $1 / 9$ & $1 / 5$ & $1 / 3$ & 1 \\
\hline
\end{tabular}

From "Table 7" to know the weight between the criterion layers $\mathrm{W} 2=(0.6427,0.2083,0.1011,0.0480)$. Calculated by $\lambda=4.0104$, the consistency check result is $\mathrm{CR}=\mathrm{CI} / \mathrm{RI}=0.0116<0.1$, meet the consistency states.

Table8. Construction environment risk (B3) group judgment matrix

\begin{tabular}{|c|c|c|c|c|c|c|}
\hline Construction environment risk & C9 & C10 & C11 & C12 & C13 & C14 \\
\hline C9 & 1 & 5 & $1 / 5$ & 5 & 3 & 3 \\
\hline C10 & $1 / 5$ & 1 & $1 / 7$ & 1 & $1 / 3$ & $1 / 3$ \\
\hline C11 & 5 & 7 & 1 & 7 & 5 & 5 \\
\hline C12 & $1 / 5$ & 1 & $1 / 7$ & 1 & $1 / 3$ & $1 / 3$ \\
\hline C13 & $1 / 3$ & 3 & $1 / 5$ & 3 & 1 & 1 \\
\hline C14 & $1 / 3$ & 3 & $1 / 5$ & 3 & 1 & 1 \\
\hline
\end{tabular}

From "Table 8" we know the weight between the criterion layers $\mathrm{W} 3=(0.2182,0.0444,0.4790,0.0444$, $0.1067,0.1067)$. Calculated using $\lambda=6.1109$. The consistency check result is $\mathrm{CR}=\mathrm{CI} / \mathrm{RI}=0.0176<0.1$, which comply with the consistency conditions.

Table9. Construction management risk (B4) group judgment matrix

\begin{tabular}{|c|c|c|c|c|c|c|}
\hline $\begin{array}{c}\text { Construction management } \\
\text { risk }\end{array}$ & $\mathrm{C} 15$ & $\mathrm{C} 16$ & $\mathrm{C} 17$ & $\mathrm{C} 18$ & $\mathrm{C} 19$ & $\mathrm{C} 20$ \\
\hline $\mathrm{C} 15$ & 1 & 5 & $1 / 5$ & 5 & 3 & 3 \\
\hline $\mathrm{C} 16$ & $1 / 5$ & 1 & $1 / 7$ & 1 & $1 / 3$ & $1 / 3$ \\
\hline $\mathrm{C} 17$ & 5 & 7 & 1 & 7 & 5 & 5 \\
\hline $\mathrm{C} 18$ & $1 / 5$ & 1 & $1 / 7$ & 1 & $1 / 3$ & $1 / 3$ \\
\hline $\mathrm{C} 19$ & $1 / 3$ & 3 & $1 / 5$ & 3 & 1 & 1 \\
\hline $\mathrm{C} 20$ & $1 / 3$ & 3 & $1 / 5$ & 3 & 1 & 1 \\
\hline
\end{tabular}

From "Table 9" we know the weight between the criterion layers $\mathrm{W} 4=(0.1131,0.0288,0.0544,0.1131$, $0.2381,0.4522)$. Calculated by $\lambda=6.0291$. The consistency check result is $\mathrm{CR}=\mathrm{CI} / \mathrm{RI}=0.0046<0.1$, meet the consistency conditions.
Table10. Construction management risk (B5) group judgment matrix

\begin{tabular}{|c|c|c|c|}
\hline Construction management risk & $\mathrm{C} 21$ & $\mathrm{C} 22$ & $\mathrm{C} 23$ \\
\hline $\mathrm{C} 21$ & 1 & 5 & $1 / 5$ \\
\hline $\mathrm{C} 22$ & $1 / 5$ & 1 & $1 / 7$ \\
\hline $\mathrm{C} 23$ & 5 & 7 & 1 \\
\hline
\end{tabular}

As showed in "Table 10", the weight between the criterion layers $\mathrm{W} 5=(0.1061,0.2605,0.6334)$. Calculated by $\lambda=3.0034$. The consistency check result is $\mathrm{CR}=\mathrm{CI} / \mathrm{RI}=0.0032<0.1, \quad$ achieve the consistency conditions.

It can be seen from "Table 4" that the highest weight of the criterion level is personnel risk (B1), which is 0.425 , construction management risk (B4) and construction technology risk (B5) are 0.301 and 0.113 respectively, followed by construction environmental risk (B3) 0.108, construction machinery risk (B2) 0.0353 . It can be seen from "Table 11" that the maximum weight of the indicator layer is "C2: Risk Awareness" in personnel risk (B1). Followed by "C20: Risk Management System" in Construction Management Risk (B4), "C1: Organizational Structure Risk" in Personnel Risk (B1), and "C23: Technical Level Risk of Construction Workers" in Construction Technology Risk (B4). In the construction environment (B3), "C10: Underground Pipeline Risk" and "C12: Ground Building Risk" are ranked in the 21st place, and the weight of construction machinery (B2) "C8: Equipment deployment risk" is the smallest.

\subsubsection{Fuzzy comprehensive evaluation}

Use the FUSS theory to transform expert evaluation language[10] to establish a comment set of the evaluation system of the subway project construction safety risk evaluation index. The comment set $\mathrm{V}=$ \{risk is small, the risk is low, the risk is generally, the risk is high, the risk is high\}, respectively represented by $1,2,3,4,5[11]$. Combining the weight of the target level of each evaluation index of construction risk and the scores of 10 risk management experts to determine the risk factor membership degree, after combing and summarizing, the risk factor membership degree is shown in "Table 12", and the grade value in "Table 12" is the number of experts who agree with this grade accounted for the proportion of all experts.

Table11. Index layer weight

\begin{tabular}{|c|c|c|c|c|c|}
\hline Target layer A & Criterion Level B & Weights & Index level C & Weights & $\begin{array}{c}\text { Total } \\
\text { weight }\end{array}$ \\
\hline \multirow{13}{*}{$\begin{array}{c}\text { Construction safety risk } \\
\text { of a subway project }\end{array}$} & \multirow{4}{*}{ Personnel B1 } & \multirow{4}{*}{0.425} & Organizational structure $\mathrm{C} 1$ & 0.2727 & 0.1159 \\
\hline & & & Risk awarenessC2 & 0.5445 & 0.2314 \\
\hline & & & Safety TrainingC3 & 0.0909 & 0.0386 \\
\hline & & & Emergency response $\mathrm{C} 4$ & 0.0909 & 0.0386 \\
\hline & \multirow{4}{*}{$\begin{array}{l}\text { Construction machinery } \\
\text { B2 }\end{array}$} & \multirow{4}{*}{0.053} & Operation useC5 & 0.6427 & 0.034 \\
\hline & & & Maintenance C6 & 0.2083 & 0.011 \\
\hline & & & Special equipment management $\mathrm{C} 7$ & 0.1011 & 0.0054 \\
\hline & & & Equipment deployment C8 & 0.0480 & 0.0025 \\
\hline & \multirow{5}{*}{$\begin{array}{c}\text { Construction } \\
\text { environment B3 }\end{array}$} & \multirow{5}{*}{0.108} & Geological watermark C9 & 0.2182 & 0.0236 \\
\hline & & & Underground pipeline $\mathrm{C} 10$ & 0.0444 & 0.0048 \\
\hline & & & Personnel construction environment C11 & 0.4790 & 0.0517 \\
\hline & & & Ground building $\mathrm{C} 12$ & 0.0444 & 0.0048 \\
\hline & & & Natural climate C13 & 0.1067 & 0.0115 \\
\hline
\end{tabular}




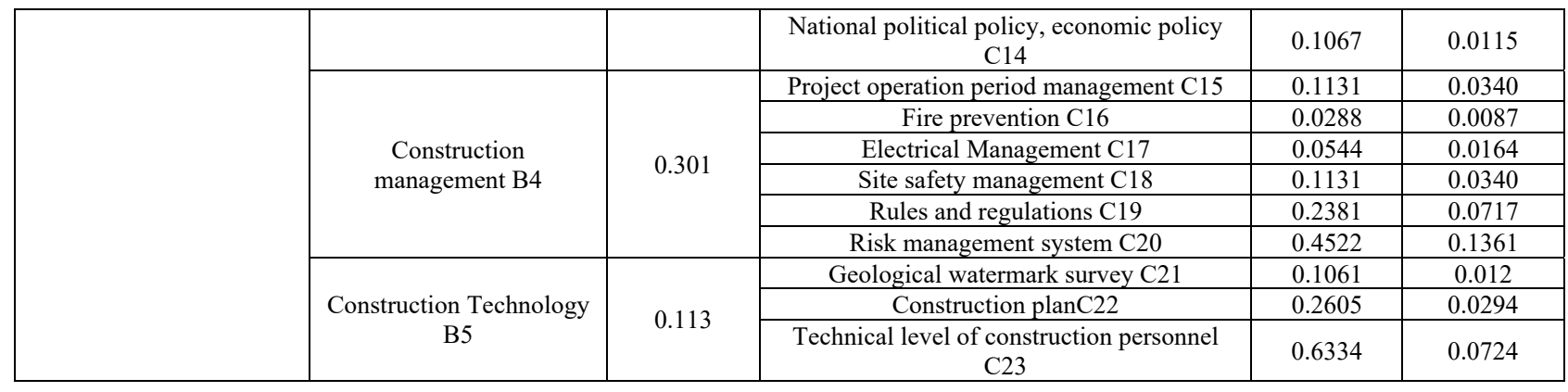

Table12. Risk Factor Membership Table

\begin{tabular}{|c|c|c|c|c|c|c|}
\hline \multirow{2}{*}{ Criterion Level B } & \multirow{2}{*}{ Index level C } & \multicolumn{5}{|c|}{ Rating } \\
\hline & & Higher & High & General & Lower & Small \\
\hline \multirow{4}{*}{$\begin{array}{l}\text { Personnel } \\
\quad \text { B1 }\end{array}$} & Organizational structure $\mathrm{C} 1$ & 0.2 & 0.4 & 0.3 & 0.1 & \\
\hline & Risk awareness $\mathrm{C} 2$ & 0.5 & 0.2 & 0.2 & 0.1 & \\
\hline & Safety Training C3 & & 0.6 & 0.3 & 0.1 & \\
\hline & Emergency response $\mathrm{C} 4$ & & 0.2 & 0.5 & 0.2 & 0.1 \\
\hline \multirow{4}{*}{ Construction machinery B2 } & Operation use $\mathrm{C} 5$ & 0.2 & 0.3 & 0.4 & 0.1 & \\
\hline & Maintenance C6 & & 0.6 & 0.3 & 0.1 & \\
\hline & Special equipment management $\mathrm{C} 7$ & & & 0.5 & 0.4 & 0.1 \\
\hline & Equipment deployment C8 & & & 0.2 & 0.6 & 0.2 \\
\hline \multirow{6}{*}{$\begin{array}{l}\text { Construction environment } \\
\text { B3 }\end{array}$} & Geological watermark C9 & & 0.6 & 0.3 & 0.1 & \\
\hline & Underground pipeline $\mathrm{C} 10$ & & & 0.4 & 0.5 & 0.1 \\
\hline & $\begin{array}{l}\text { Personnel construction environment } \\
\text { C11 }\end{array}$ & 0.1 & 0.4 & 0.5 & & \\
\hline & Ground building $\mathrm{C} 12$ & & 0.3 & 0.5 & 0.2 & \\
\hline & Natural climate $\mathrm{C} 13$ & & & 0.2 & 0.6 & 0.2 \\
\hline & $\begin{array}{c}\text { National political policy, economic } \\
\text { policy C14 }\end{array}$ & & & 0.2 & 0.5 & 0.3 \\
\hline \multirow{6}{*}{$\begin{array}{c}\text { Construction Management } \\
\text { B4 }\end{array}$} & $\begin{array}{l}\text { Project operation period management } \\
\text { C15 }\end{array}$ & 0.2 & 0.3 & 0.4 & 0.1 & \\
\hline & Fire prevention C16 & & & 0.4 & 0.5 & 0.1 \\
\hline & Electrical Management C17 & & 0.3 & 0.4 & 0.3 & 0.1 \\
\hline & Site safety management $\mathrm{C} 18$ & 0.1 & 0.2 & 0.6 & 0.1 & \\
\hline & Rules and regulations $\mathrm{C} 19$ & & 0.3 & 0.4 & 0.3 & 0.2 \\
\hline & Risk management system C20 & 0.1 & 0.4 & 0.3 & 0.2 & \\
\hline \multirow{3}{*}{ Construction Technology B5 } & Geological watermark survey C21 & & 0.1 & 0.4 & 0.5 & \\
\hline & Construction plan $\mathrm{C} 22$ & & 0.1 & 0.4 & 0.4 & 0.1 \\
\hline & $\begin{array}{l}\text { Technical level of construction } \\
\text { personnel C23 }\end{array}$ & 0.2 & 0.2 & 0.5 & 0.1 & \\
\hline
\end{tabular}

According to "Table 12", from the fuzzy evaluation vector calculation formula $\mathrm{Bi}=\mathrm{AiRi}$, the fuzzy evaluation vectors of the criterion layer are calculated as:

$\mathrm{B}_{1}=\mathrm{W}_{1} \mathrm{R}_{1}=(0.3268,0.2917,0.2634,0.1090,0.0091)$

$\mathrm{B}_{2}=\mathrm{W}_{2} \mathrm{R}_{2}=(0.1285,0.3178,0.3797,0.1543,0.0197)$

$\mathrm{B}_{3}=\mathrm{W}_{3} \mathrm{R}_{3}=(0.0480,0.3360,0.3877,0.1704,0.0579)$

$\mathrm{B}_{4}=\mathrm{W}_{4} \mathrm{R}_{4}=(0.0690,0.3140,0.3561,0.2051,0.0558)$

$\mathrm{B}_{5}=\mathrm{W}_{5} \mathrm{R}_{5}=(0.1267,0.1633,0.4633,0.2206,0.0261)$

According to the principle of maximum subordination, personnel risk is "higher"; construction machinery risk is "higher"; construction environmental risk is "higher"; construction management risk is "higher"; construction technology risk is "high".

According to "Table 12", the fuzzy evaluation matrix of the criterion layer is introduced, and then the fuzzy evaluation matrix of the index layer is obtained as shown in formula (3).

$$
R=\left[\begin{array}{lllll}
0.3268 & 0.2917 & 0.2634 & 0.1090 & 0.0091 \\
0.1285 & 0.3178 & 0.3797 & 0.1543 & 0.0197 \\
0.0480 & 0.3360 & 0.3877 & 0.1704 & 0.0579 \\
0.0690 & 0.3140 & 0.3561 & 0.2051 & 0.0558 \\
0.1267 & 0.1633 & 0.4633 & 0.2206 & 0.0261
\end{array}\right]
$$

The calculation of the weight vector of the criterion layer is shown in formula (4).

$$
\mathrm{W}_{\mathrm{Bi}}=\left[\begin{array}{lllll}
0.425 & 0.053 & 0.108 & 0.301 & 0.113
\end{array}\right]
$$

The index level fuzzy matrix is shown in formula (5).

$$
Y=W_{B i} R=\left[\begin{array}{lllll}
0.1860 & 0.2901 & 0.3335 & 0.1595 & 0.0309
\end{array}\right]
$$

The construction environmental risk of the subway project is "higher" and construction machinery risk is "general".

\section{RISK MANAGEMENT MEASURES}

Wu Wenli[12] believes that we need to improve the risk management process, pay attention to risk transfer, and do a good job in risk retention; Teng Li[13] proposes the use of communication and information technology to carry out the whole process and all-round risk management of project construction; Qian Qihu[14] integrates new information technology into risk management technology to improve risk management effects. Fully consider the characteristics of underground engineering construction, and put forward risk management measures in five aspects: personnel, machinery, environment, management, and technology.

Personnel risk management measures. Establish a risk management department; whole-process risk management; whole-process risk reminders; organize safety knowledge and skills training; organize regular emergency response drills for common accidents to strengthen the emergency response capabilities of all employees.

Risk management measures for construction machinery. Strengthen personnel and equipment operation 
capabilities; pre-job certification and assessment; do a good job in equipment maintenance; pay attention to special equipment management; the person in charge of construction masters equipment performance; dynamically tracks construction plans, personnel operation capabilities.

Construction environmental risk management measures. Do a good job in the geology and watermark survey of the construction area; master the purpose and direction of the underground pipeline; understand the construction structure of the ground building; understand the climatic characteristics of the construction area within 10 years; understand the national political and economic policies.

Construction management risk management measures. Formulate risk management and construction safety rules and regulations; conduct daily safety inspections; do a good job in fire prevention equipment inspection and common fire source management; do a good job in electrical positioning; check circuits before and after construction.

Construction technology risk management measures. Organize the construction party, Party A, the project leader and experts in related fields to discuss the feasibility of the scheme; organize the technical evaluation of the construction personnel; the technical supervision and evaluation of the whole process; after the construction, the ability of the technicians and operators is evaluated.

\section{CONCLUSION}

Through qualitative and quantitative analysis, it could be closed that the tram project, except for the high risk of construction technology, the risks of other stages are all high risks, and the generally danger of the task will be generally helter skelter. The risk management model needs to shift from focusing on post-incident analysis to focusing on pre-construction risk analysis, risk system construction, and risk awareness training, to achieve the risk management goal of "accidents preventable and risk controllable" and reduce the occurrence of safety accidents in underground engineering construction.

\section{References}

1. J.Zhu,H.H.,Luo,X., Peng,X.L.(2017).Research on the Development Strategy of Urban Underground Space Planning in China. Chinese Engineering Science, 19:12-14.

2. J.Qian,Q.H.(1998).Sustainable Urban Development and Underground Space Development and Utilization. Journal of Underground Space and Engineering, 18:69-75

3. J.Qian,Q.H.(2012).Challenges and Countermeasures of Underground Engineering Construction Safety.Engineering Technology,31:45.

4. J.Tang,Y.C.(2018).Summary of Research on Safety Risk Management of China's Metro Engineering. Journal of Engineering Management,32:69-74.
5. J.Pan,X.M,Wang,G.F,Wang,G.H.(2008).A Summary of Environmental Risk Management and Disposal Schemes for Beijing Metro Engineering Construction. Construction Technology,37:65-69.

6. J.Shen,X.P,Yuan,Y.B.(2019).Application of Rough Set Theory in Risk Management of Underground Engineering.Journal of Shijiazhuang Institute of Railway Technology, 18:44-49.

7. D.Wang,Y.L.Research on Construction Safety Risk Management of Matan-Tumendun Section of Lanzhou Metro Line 1.Lanzhou:Lanzhou Jiaotong University, 2020.

8. J.Cheng,E.W.L,Li,H.(2001)Analytic hierarchy process: An approach to determine measures for businessperformance.Measuring Business Excellence, 5:30-37.

9. J.Ju,L.J,Yi,M.W .Jing,D.(2004)Fuzzy comprehensive evaluation model based on improvedanalytic hierarchy process.Journal of Hydraulic Engineering, 2:144-147.

10. J.Zhang,X.F,Zheng,J.G.(2009).Research on Information System Supplier Evaluation Based on Fuzzy AHP and Fuzzy Evaluation. China Management Information, 12:86-89.

11. D.Zhao,Y.Research on Financial Risk Evaluation in Science Fund Management.Hefei:Hefei University of Technology,2010

12. J.Wu,W.L.(2015).Analysis of Risk Management in the Construction of Tunnels and Underground Engineering.Journal of Hunan University of Science and Technology,36:76-78.

13. J.Teng,L(2011).Application of Intelligent Risk Management System in Shield Tunnel Engineering. Building Construction, 33: 742-745.

14. J.Qian,Q.H.(2017).Main progress and development direction of geological forecast and information technology in tunnel engineering construction. Tunnel construction, 3:251-26. 